\title{
Schopenhauer and Secular Salvation in the work of J.M. Coetzee
}

\section{Richard Alan Northover}

\begin{abstract}
Amazing Grace, how sweet the sound,
That saved a wretch like me,

I once was lost, but now am found,

Was blind, but now I see.
\end{abstract}

John Newton (1779) ${ }^{1}$

The verses in the epigraph are from a Christian hymn written by the former captain of a slave ship involved in the Atlantic slave trade who eventually converted to Christianity and repented his role in the slave trade for the rest of his life. His hymn is based on a prayer by King David (1 Chronicles 17: 16-17) and expresses gratitude for moments of grace in which he was saved from sin. His work as a priest inspired William Wilberforce, whose efforts to abolish the slave trade in Britain eventually succeeded in 1823. Newton's story raises interesting questions about personal and general complicity in an evil institution such as slavery considered normal at the time (hence analogous to our contemporary animal exploitation industries), and about whether there is a need for divine intervention, or moments of grace, to achieve salvation, questions at the heart of much of Coetzee's writing.

The idea of salvation is one of the most perplexing themes in Coetzee's writings. It is not clear why a secular writer like Coetzee should feel the need to use the biblical narrative of the fall, grace and redemption at all. I will investigate in this paper the possibility that Coetzee explores the idea of salvation not merely in terms of individual lapses into sin or in terms of complicity in unjust political or economic systems, but also in a much deeper metaphysical sense, in terms of Schopenhauer's idea that existence - one's egoistic bondage to the universal will - is itself a fall into sin from which each individual requires redemption, and that grace is the denial of the will-to-life (Will I 405).

Considering the apparent affinity of Schopenhauer's philosophy with J.M. Coetzee's concern for animals, most clearly displayed in Disgrace and The Lives of Animals, the critical

\footnotetext{
${ }^{1}$ This paper is largely a reworking of chapters 5 and 6 of my PhD thesis (2010), and represents a profound change of emphasis from the Socratic optimism I argued in an earlier paper ("Elizabeth Costello as a Socratic Figure," English in Africa 39.1 [2012]) to a Schopenhauerian pessimism, which seems closer to the ethos of Coetzee's fictional worlds.
} 
neglect of this philosopher seems surprising. Schopenhauer was a Romantic philosopher who, according to John Gray, provided the "first and still unsurpassed critique of humanism” (38), who challenged the Enlightenment belief in Reason and Progress, and who firmly embedded humanity in the animal world and completely embodied mind in body, pre-empting Darwin, sociobiology and deep ecology. His deep pessimism, his vociferous opposition to vivisection, his belief in secular salvation through art (especially music), and his basing ethics on compassion rather than reason are only some of the more obvious points of convergence with Coetzee.

None of the analytic philosophers who have responded to Coetzee (Singer, Hacking, Diamond, Mulhall) except Cavalieri (9-10, 20) mentions Schopenhauer, despite Coetzee's occasional references to Schopenhauer in his critical writings (Stranger 152-53, 168, 171; Inner Workings 4, 10, 31) and despite their common emphasis on compassion. A recent book entitled J.M. Coetzee and Ethics: Philosophical Perspectives on Literature (Leist and Singer) does not make a single reference to Schopenhauer. One of the contributors discusses Nietzsche in depth in relation to Coetzee but does not acknowledge Schopenhauer's influence on Nietzsche, not even the fact that Nietzsche's attack on asceticism as an ideal is largely a rejection of Schopenhauer's ethics.

However, there is evidence of a renewed interest in Schopenhauer among contemporary thinkers, including, perhaps surprisingly, some in the feminist care tradition (Donovan 175-76; Kelch 285). Although Josephine Donovan mentions Coetzee in the introduction to The Feminist Care Tradition in Animal Ethics (15) and discusses Schopenhauer in the body of the book (177), she does not link the two explicitly, even though she has written an article - "Miracles of Creation” - on the ethics of sympathy in Coetzee. John Gray (38-42) has explored Schopenhauer in terms of ecology and Laurence Wright ("Ecological” 24-42) has made the link between ecology, Schopenhauer and J.M. Coetzee, going some way to remedy the critics' neglect of this philosopher. Graham Bradshaw (191-93) compares Schopenhauer's idea of pity with those of Kant and Nietzsche in relation to Coetzee, Costello and Conrad. Carrol Clarkson (112), discussing an article by Michiel Heyns, notes the influence of Thomas Hardy's Jude the Obscure on Disgrace - not least its use of the phrase "because we are too menny," which Coetzee refers to in Disgrace $(85,146)$ and The Lives of Animals (52) - but questions the influence of Schopenhauer on Hardy. However, a strong case can be made for the contrary position, and Coetzee himself considers this possibility (Stranger 152-53). That Coetzee's use of 
the poetry of Ted Hughes in The Lives of Animals $(50-55,65)$ reinforces the Schopenhauerian connection is confirmed by the essay by Dwight Eddins (94-109) which discusses Ted Hughes's poetry in relation to that philosopher. However, while Eddins focuses on Schopenhauer's will-tolife, this paper will emphasize his ideas on compassion and salvation.

Though several critics have remarked on the apparent pessimism of Coetzee's novels (Lowry, Heyns), particularly Disgrace, no one, with the exception of Laurence Wright, has linked it to Schopenhauer's philosophy. Wright provides an excellent summary of Schopenhauer's epistemology, metaphysics and ethics - compassion as the basis of both justice and philanthropy - and relates it to the present ecological crisis and the onslaught of capitalism on the environment, seeing the inherent egoism of capitalism as an expression of an insatiable Schopenhauerian will. I would contest Wright's use of the term “philanthropy,” however, since the positive side of Schopenhauer's ethics - loving-kindness - is not limited to human beings. In this paper I intend to extend and elaborate, to corroborate and to problematize, Wright's Schopenhauerian insights into Coetzee’s critical and Costello pieces - particularly "As a Woman Grows Older,” “The Humanities in Africa” and The Lives of Animals - and in Disgrace.

I will argue that the ideas of pessimism, grace and salvation operate in the works of Coetzee on three levels - writer, reader and theme - and in two basic modes, the Nietzschean and the Schopenhauerian. Whereas Schopenhauer emphasizes redemption from suffering through compassion, resignation and the contemplation of art, Nietzsche emphasizes the embracing of suffering through artistic creativity. As a writer, Coetzee himself attempts to come to terms with suffering by means of his sympathetic imagination and thereby to empower the reader to do the same; in his Jerusalem Prize Acceptance Speech he remarked: "We have art, says Nietzsche, so that we shall not die of the truth” (99).

In the interview preceding his essay, "Confession and Double Thoughts: Tolstoy, Rousseau, Dostoevsky," in Doubling the Point, Coetzee distinguishes between religious and secular confessions (251-52) and relates confession to a process of transgression, penance and absolution (251). In a later interview, he notes that the terms brought into prominence in the essay are cynicism and grace: “Cynicism: the denial of any ultimate basis for values. Grace: a condition in which the truth can be told clearly, without blindness” (392). In the Introduction to Doubling the Point, David Attwell offers grace as one way of achieving closure but 
acknowledges, with Coetzee, the difficulty of transferring religious terms to a non-religious context (11).

Coetzee concludes his essay thus: "True confession does not come from the sterile monologue of the self or from the dialogue of the self with its own self-doubt, but [. . .] from faith and grace" (291). Attwell reiterates the need for grace and the lack of a secular equivalent in the interview that precedes the essay (247). Coetzee's answer to this involves the body and the pain that it can feel: "Whatever else, the body is not 'that which is not,' and the proof that it is the pain it feels. The body with its pain becomes a counter to the endless trials of doubt” (248). He continues:

\begin{abstract}
Not grace, then, but at least the body. Let me put it baldly: in South Africa it is not possible to deny the authority of suffering and therefore of the body. [. . .] [I]t is not that one grants the authority of the suffering body: the suffering body takes this authority: that is its power. To use other words: its power is undeniable.

(Let me add entirely parenthetically that I, as a person, as a personality, am overwhelmed, that my thinking is thrown into confusion and helplessness, by the fact of suffering in the world, and not only human suffering. These fictional constructions of mine are paltry, ludicrous defenses against that beingoverwhelmed, and, to me, transparently so.)
\end{abstract}

This suggests that Coetzee is concerned with the problem of suffering - including that of nonhuman animals - at the deepest level, the level at which the idea of suffering and its removal (hence salvation) are at the heart of Buddhist teachings and of Christian theodicy. It also suggests that suffering itself is necessary for salvation. It seems strange that a secular and progressive writer like Coetzee would apparently subscribe to the idea of the 'mystification of suffering' but it is undeniably to be found in much of his fiction, and I intend to provide a rational and secular justification for this.

Coetzee emphasizes the importance of Dostoevsky in achieving closure to the apparent endlessness of confession, employing the term "grace:"

Against the endlessness of skepticism Dostoevsky poses the closure not of confession but of absolution and therefore of the intervention of grace in the world. [. . .] What saves me from a merely stupid stupidity, I 
would hope, is a measure of charity, which is, I suppose, the way in which grace allegorizes itself in the world.

This is an explicit although qualified identification of grace with compassion. However, when Attwell asks Coetzee later in the interview whether the ending of Age of Iron can be interpreted allegorically as representing the intervention of grace and whether Elizabeth Curren can be seen to have achieved absolution, Coetzee is evasive about the possibility of grace:

As for your question about absolution for Elizabeth, the end of the novel seems to me more troubled (in the sense that the sea can be troubled) than you imply. But here I am stepping onto precarious ground, on precarious water; I had better stop. As for grace, no, regrettably no: I am not a Christian, or not yet.

This leads to the question of how salvation is possible in a post-Christian world without recourse to the idea of God's saving grace. I argue that Schopenhauer's philosophy can provide a coherent account of (moments of) secular salvation by means of art, contemplation and compassion that usefully illuminates Coetzee's ethics. I will now proceed to trace Coetzee's use of the terms "grace" and "salvation" in his Costello pieces before going on to explore his use of these terms in Disgrace.

The term "grace” is discussed in one of Coetzee’s Costello stories. In “A Woman Grows Older," Costello is driving with her daughter through the French countryside, the beauty of which becomes the subject of their conversation. Characteristically, Costello expresses doubts about her lifelong pursuit of beauty:

\footnotetext{
"The question I find myself asking now is, What good has it done me, all this beauty? Is beauty not just another consumable, like wine? One drinks it in, one drinks it down, it gives one a brief, pleasing, heady feeling, but what does it leave behind? The residue of wine is, excuse the word, piss; what is the residue of beauty? What is the good of it? Does beauty make us better people?”
}

Costello's questioning of the link between beauty and ethics is particularly significant, suggesting that she, and presumably Coetzee, thinks writing should have a moral function 
beyond, or in addition to, the mere production (for consumption) of beauty. Helen provides an answer to Costello’s questions:

\footnotetext{
"The answer you will not give - because it would be out of character for Elizabeth Costello - is that what you have produced as a writer not only has a beauty of its own - a limited beauty, granted, it is not poetry, but beauty nevertheless, shapeliness, clarity, economy - but has also changed the lives of others, made them better human beings, or slightly better human beings. It is not just I who say so. Other people say so too, strangers. To me, to my face. Not because what you write contains lessons but because it is a lesson.

"You teach people how to feel. By dint of grace. The grace of the pen as it follows the movements of thought.
}

Here, despite some apparently ambivalent feelings, Coetzee, through his Costello persona, appears to be expressing the idea that art in general and fiction in particular can make the world a better place, by using the sympathetic imagination to nurture compassion in his readers.

Another Costello story, "The Humanities in Africa," provides support for a Schopenhauerian interpretation of Coetzee - perhaps surprisingly, because the Roman Catholicism in the story would seem to contradict Schopenhauer's atheism. But (as an atheist) Schopenhauer thought that Roman Catholicism was the true version of Christianity, with its emphasis on suffering and its affinities with the pessimistic Far Eastern religions. Of course, this would require taking the main narratives and supernatural metaphysics of Christianity as allegories for Schopenhauer's own metaphysics, something most Catholics would not accept.

For Schopenhauer, existence itself is a fall from grace (non-existence) into a world of suffering and bondage to the blind will-to-life, in a world that "is the battle-ground of tormented and agonized beings who continue to exist only by each devouring the other" (Will II 581). He sees the Christian ideas of Adam's fall from grace (original sin) and redemption through Christ's crucifixion as mythological expressions of this metaphysical truth (World I 355, 404-405). "In the New Testament, the world is presented as a vale of tears, life as a process of purification, and the symbol of Christianity is an instrument of torture” (World II 584). Compassion, one of few sources of salvation, is the recognition that, behind the phenomenal illusion of separation, we are all one, all expressions of a single, universal, undifferentiated noumenal Being. This will-to-life 
is not personal or benevolent, but rather a blind striving for existence. The fall from grace into a world of suffering explains why tolerance, charity, compassion, and other virtues are necessary (Essays 49-50). In relation to ethics, Schopenhauer contrasts Old Testament Judaic Law versus New Testament Grace and argues that Christian ethics "preaches the kingdom of grace, which one can enter through faith, charity and total denial of the self: this, it says, is the road to redemption from evil and the world: for - every Protestant and Rationalist misrepresentation notwithstanding - the true soul of the New Testament is undoubtedly the spirit of asceticism” (62). He also characterizes the Old Testament as realist and optimist, the New, as idealist and pessimist, like Hinduism and Buddhism (181-89). Schopenhauer's belief in grace, despite his atheism and pessimism, also shows how Coetzee's secular idea of salvation is possible (a salvation in which art and music play a leading role). Yet Coetzee submits these ideas to intensive interrogation in the Costello pieces, particularly in "The Humanities in Africa."

In this story, Elizabeth Costello is invited to attend a graduation ceremony for humanities students at a university in Johannesburg at which her sister Blanche - more famous as the Catholic nun Sister Bridget - is to be awarded an honorary doctorate for her work with Aids orphans in KwaZulu-Natal. In her acceptance speech, Sister Bridget tells her audience that the humanities have failed to provide salvation for humanity, a theme that is taken up again at the dinner following the ceremony. Elizabeth Costello finds disconcerting her private conversation with her sister immediately following the dinner and her visit, the next day, to the Marianhill Hospital, where she experiences at first hand her sister's idea of salvation. In their conversation after the dinner, Blanche points out what she sees as the failure of Hellenism, which, according to her, was "the one alternative to the Christian vision that humanism was able to offer" (131). Costello tries to defend later expressions of the humanities that followed Hellenism, arguing that they had merit in trying to improve conditions for humans in the world. Blanche replies: "Yes. And therein they reveal themselves as true followers of their humanist forebears. Who offered a secular vision of salvation. Rebirth without the intervention of Christ. By the workings of man alone. Renaissance. [. . .] Well, it cannot be done” (133). When Costello suggests that Blanche sees damnation for all of those who seek salvation outside of the Catholic Church, her sister concludes: "I said nothing of damnation. I am talking only about history, about the record of the humanist enterprise. It cannot be done. Extra ecclesiam nulla salvatio” (133). 
The divergence between Costello's and her sister's world-views is especially evident in their different attitudes to art. Costello is appalled by the single-minded devotion of Joseph, the resident carver at Marianhill, to carving the same image of the crucified Christ his whole life until arthritis ends his craft: "What does it do to a person's - if I dare to use the word - soul to spend his working life carving a man in agony over and over again?” (137). Blanche replies at length, concluding, "Which of us, I now ask, will Jesus be most gladdened to welcome into his kingdom: Joseph, with his wasted hands, or you, or me?” (138). Against Blanche’s vision of art serving religion, Costello pits the Greek ideal of bodily youth and beauty:

\footnotetext{
"I am asking what you, you yourself, have against beauty. Why should people not be able to look at a work of art and think to themselves, That is what we as a species are capable of being, that is what I am capable of being, rather than looking at it and thinking to themselves, My God, I am going to die, I am going to be eaten by worms?” [Coetzee’s italics]
}

Blanche argues that Greek ideals were not foreign to the Zulus, and that "when Europeans first came in contact with the Zulus, educated Europeans, men from England with public-school educations behind them, they thought they had rediscovered the Greeks” (140). Yet, according to Blanche, when the colonial administrators offered the Zulus a kind of secular salvation, the elimination of disease, poverty and decay through reason and the sciences, the Zulus chose Christ instead because they knew better, as "they [especially African women] suffer and [Christ] suffers with them” (141). When Costello asks whether it is not because he promises them another, better life after death, Blanche replies: "No. To the people who come to Marianhill I promise nothing except that we will help them bear their cross” (141). This is a stark, unattractive vision of salvation, which has no place for Greek ideals of beauty or of the redemptive powers of art. It also seems a bit naïve in failing to locate the source of African poverty and suffering in colonialism and apartheid, apparently assuming that such suffering is inevitable. Nonetheless, it has much in common with Schopenhauer's philosophy and it is a position forcefully expressed by Blanche, so forcefully, indeed, that it seems to overwhelm Costello's humanism. Indeed, it may well represent Coetzee's own doubts about his lifelong work in the humanities and his serious consideration of the profound moral significance of the 
Christian tradition with its focus on suffering and compassion, even if he, like Schopenhauer, presumably rejects literalist interpretations of the biblical myths.

Blanche is relentless. Instead of trying to part with her sister amicably - most likely their last parting before they die - she takes the opportunity to have the last word, speaking on behalf of the Africans:

“[. . .] remember it is what they have made of [Christ], they, the ordinary people. What they have made of him and what he has let them make of him. Out of love. [. . .] Ordinary people do not want the Greeks. They do not want the realm of pure forms. They do not want marble statues. They want someone who suffers like them. Like them and for them.

$[\ldots]$

"You backed a loser, my dear. If you had put your money on a different Greek you might still have stood a chance. Orpheus rather than Apollo. The ecstatic instead of the rational. Someone who changes form, changes colour, according to his surroundings. Someone who can die but then come back. A chameleon. A phoenix. Someone who appeals to women. Because it is women who live closest to the ground. Someone who moves among the people, whom they can touch - put their hand into the side of, feel the wound, smell the blood. But you didn’t, and you lost. You went for the wrong Greeks, Elizabeth.”

(144-45)

Coetzee submits his belief in humanism to intense criticism in this extract and seriously considers an alternative tradition. This rejection of rationalism and emphasis on suffering and compassion resonates strongly with Schopenhauer's philosophy. Where Schopenhauer differs from the Christian tradition and more closely resembles Coetzee is in his atheism and his concern for animals, the latter being considered unimportant by mainstream Christianity.

In an earlier paper (mentioned in the first footnote), I argued that Coetzee can be seen as offering an optimistic Socratic virtue ethic as opposed to either an Aristotelian or a Nietzschean one, a claim apparently borne out by the dialogic form of Coetzee’s work. However, it will be argued here that a Schopenhauerian ethic would appear better to illuminate Coetzee's apparent pessimism, his emphasis on suffering, his dismissal of reason and his espousal of compassion. Indeed, the Schopenhauerian interpretation, considering his approval of the Far Eastern religions, appears to be reinforced by the description of Costello by her son John in "What Is Realism?:" "His mother is not in the Greco-Roman mould. Tibet or India more like it: a god incarnated in a child, wheeled from village to village to be applauded, venerated” (31). 
This is further corroborated by Coetzee's comments in The Death of the Animal, a philosophical dialogue by the philosopher Paolo Cavalieri in which two philosophers discuss animal ethics and during the course of which the analytic philosopher, Alexandra, convinces the continental philosopher, Theo, to convert to vegetarianism. In a response to the dialogue, Coetzee comments that the interlocutors are "children of Socrates" and "appear to have transcended those passions and appetites that we might call animal or, equally well, human” (Cavalieri 85). Coetzee notes further that:

There are people (not many professional philosophers among them) to whom brawling and guzzling and fucking represent, if not the highest activities of life, the activities during whose performance they feel most themselves - the activities that allow them to live out their being-in-the-world most fully.

This passage arguably shows Coetzee's awareness of what can be described as people's bondage to a Schopenhauerian will, and reveals his doubt that most people can be convinced to change their minds concerning basic ethical matters by means of logic and reasoning alone; indeed, his doubt that much of human behavior is predominantly rational, reflective or even moral. Cavalieri refers to Schopenhauer in her dialogue, although she is critical of ethics that are based on a metaphysical system as his appears to be:

\begin{abstract}
"If you accept a philosophical interpretation of the world, you are guided and motivated by its insights. Just to mention an author who did have an interest, albeit minor, in the animal question, Arthur Schopenhauer: if one is convinced by his 'will metaphysics,' and by the theory of morals issuing from it, one will naturally embrace compassion, even toward nonhumans. Perhaps one will also embrace self-renunciation.”
\end{abstract}

Cavalieri fails to do justice to Schopenhauer when she describes his concern with animals to be "minor," when she implies that an acceptance of his ethics is dependent on an acceptance of his metaphysics (since he specifically develops his ethics without reference to his metaphysical system in his essay "On the Basis of Morals"), and when she argues that one would follow his ethics if one were to understand and intellectually accept his metaphysics (since Schopenhauer argues that a genuinely ethical response does not follow from intellectual 
understanding but from compassion). What is striking, though, is the closeness of Schopenhauer's ethics to the Levinasian ethics endorsed by Coetzee and the continental philosophers who comment on Cavalieri's dialogue. When Coetzee writes about the "conversion experience” (89) that occurs in an ethical encounter, and is required for a genuine ethical experience, he comes close to Schopenhauer's moments of grace when, through compassion for the suffering other, one transcends one's egoism. Also, when Cary Wolfe quotes Derrida's “suffering, pity and compassion” (Cavalieri 126), he could just as well have been quoting Schopenhauer. At the same time, unlike the continental philosophers who view the extension of human rights to animals with suspicion, Schopenhauer, by basing justice on compassion, can accommodate the rights approach to animal ethics characteristic of the analytic philosophers. Finally, Schopenhauer shares with the continental philosophers the belief that ethics is not purely or even largely a rational enterprise.

Indeed, Schopenhauer's philosophy can help to explain Elizabeth Costello’s paradoxical attack on reason in The Lives of Animals as the supposed basis of ethics: "Both reason and seven decades of life experience tell me that reason is neither the being of the universe nor the being of God” (23). In his essay “On the Basis of Morals,” Schopenhauer critiques Kant's commands of abstract reason, demythologizing them and showing their theological basis in the Ten Commandments, despite their apparent reliance on reason rather than divine authority (Ethics 138). According to Schopenhauer, without God the categorical imperative is unfounded, unlike compassion, which is grounded in the natural feelings of sympathy that we have for the suffering other (217). This illuminates Costello’s comment in The Lives of Animals that “[i]f principles are what you want to take away from this talk, I would respond, open your heart and listen to what your heart says" (37). Schopenhauer's critique of rational ethics also helps make sense of Costello's response to President Garrard's question at the dinner following her speech, about whether her vegetarianism “comes out of moral conviction” (43):““No, I don’t think so,’ says his mother, 'It comes out of a desire to save my soul'” (43).

That is, Costello is not vegetarian on account of a rational decision based on understanding some ethical principle but rather on a non-rational desire for salvation, based on the feeling of compassion for the suffering of animal others. Her pronouncement also echoes her discussion of the moral or psychological pollution of the Nazi perpetrators of the Holocaust, the realization of which most probably explains the uneasy silence of her dinner companions, since it 
implicates them as polluted consumers of the products of the animal exploitation industries. This is so despite her claim that she wants "to find a way of speaking to fellow human beings [. . .] that will bring enlightenment rather than seeking to divide us into the righteous and the sinners, the saved and the damned, the sheep and the goats" (22). This discourse of salvation is echoed by her daughter-in-law, Norma, near the end of the dialogue when she compares Costello to "the other preachers and their crazy schemes for dividing mankind up into the saved and the damned” (68).

Schopenhauer's ethics of compassion also illuminates Costello's claim about the perpetrators of the Holocaust, that "[t]hey refused to think themselves into the place of their victims” (Lives 34), and that:

"In other words, they closed their hearts. The heart is the seat of a faculty, sympathy, that allows us to share at times the being of another. Sympathy has everything to do with the subject and little to do with the object, the 'another' [. . .]. There are some people who have the capacity to imagine themselves as someone else, there are people who have no such capacity (when the lack is extreme, we call them psychopaths), and there are people who have the capacity but choose not to exercise it.” [Coetzee’s italics]

In Schopenhauer's terms, the perpetrators (and collaborators) failed to recognize the truth that “[t]ormented and tormentor are one” (World I 354). For Schopenhauer:

[. . .] weeping is sympathy with ourselves, or sympathy thrown back to its starting-point. It is therefore conditioned by the capacity for affection and sympathy, and by the imagination. Therefore people who are hard-hearted or without imagination do not readily weep [. . . . [Schopenhauer’s italics]

In words that seem to be echoed by Costello when she speaks of entering into the being of others (including animal-others), Schopenhauer argues that through compassion we do not imagine ourselves as suffering like the other, but we become the suffering other: "We suffer with him, thus in him: we feel his pain as his and do not imagine it as ours” [Schopenhauer's italics] (Ethics 215). This is only possible if we understand that moments of compassion involve the sundering of the veil of Maya, of the illusion that our phenomenal selves are separate, whereas, in fact, we share our noumenal being - the universal will-to-life - in common. This is one form 
of salvation, even though it is only momentary, and it is the path on which Costello is already travelling, thanks to her writerly capacity for sympathetic imagination. This knowledge of universal suffering is not an intellectual but a felt knowledge.

The road to salvation through art manifests itself in The Lives of Animals in two other ways. First, it allows Coetzee to embrace, through his writing, the idea of universal suffering that threatens to overwhelm him. Secondly, it may awaken sympathy in the hearts of his readers and thereby lead to their moral improvement, and thus to their (partial) salvation.

Besides the idea of grace and salvation reflected in the epigraph of this paper, two details in John Newton's hymn have special relevance to Disgrace. The first is that the protagonist of the novel, David Lurie, shares the name of the King whose experience of grace inspired John Newton to write the hymn, making a Jewish connection that is relevant to the Holocaust references in the novel. The second is that it is a sweet sound that brings grace to the writer of the hymn, suggesting the importance of music for salvation, something which Wright has discussed in detail. The fact that it is music, amongst other experiences, that helps Lurie to transcend his egoism for brief moments is particularly significant in Schopenhauerian terms since, for Schopenhauer, music is the highest form of art, "an entirely universal language" (World I 256) and “a copy of the will itself” [Schopenhauer's italics] (257). In Disgrace, David Lurie has moments of grace, of temporary respite or salvation from his bondage to the will, both through art and acts of compassion in relation to the dogs in the clinic that he (like a Judas goat) assists in killing and whose bodies he tries to cremate honorably (evoking the Holocaust), although he never appears fully to comprehend the reasons for his actions.

Derek Attridge makes some important observations in J.M. Coetzee and the Ethics of Writing about the embeddedness of the word "grace" in the title of the novel Disgrace and in numerous other instances: Lurie’s ex-wife mis-remembering Lucy's lover's name as “Grace," a dog's "period of grace" at the clinic, the "coup de grâce" that the intruder fails to deliver to the dog he wounds in its throat, Lurie's considering that castration is not a "graceful solution" to the urgings of desire and the fact that "ageing is not a graceful business" (177-78). Attridge notes that among the many verbal doublets that Coetzee includes in his novel, "we don't find disgrace/grace," even though it seems as if "the term is present in a ghostly way through much of the text" (178). He continues: 
"Grace" is not, as it happens, the opposite of "disgrace." The opposite of disgrace is something like "honor;" the OED definition of "disgrace” links it frequently with "dishonor." Public shame, in other words, is contrasted with, and can only be canceled by, public esteem, disgrace is redeemed by honor. Lurie spurns the opportunity to escape disgrace by means of public confession, and he makes little attempt to regain a position of public honor after his shaming.

Thus, while David Lurie, after his affair with one of his students leads to his dismissal, accepts that he must live in a permanent state of disgrace, he does, after painful personal suffering and through experiencing the suffering of others, experience moments of grace which lead to partial salvation from his bondage to the will-to-life. These moments are brief, however, as he invariably lapses into the affirmation of life that is natural to all beings. The Schopenhauerian will-to-life is not conscious and purposeful, but an unconscious striving for existence shared by all living things, and its strongest manifestation is the sexual drive (World II 533). This sexual drive is an important motif in Disgrace, not only in terms of the protagonist David Lurie's behaviour towards the various women with whom he has sexual relations, but also in terms of his thoughts and words. Indeed, the very opening of the novel reflects the protagonist's complacency about sex that, as Michiel Heyns has observed (58), seems destined to lead to a fall: "For a man of his age, fifty-two, divorced, he has, to his mind, solved the problem of sex rather well” (1). This attitude, however, is soon qualified by a reference to the Greek tragic play Oedipus, expressing a sentiment the pessimism of which Schopenhauer would approve of (and which he himself was fond of quoting): "Call no man happy until he is dead" (2).

According to Schopenhauer, the individual is deluded by nature into thinking that his or her sexual pleasure is in his or her own interest, whereas in fact it merely serves the propagation of the species (World I 276, World II 538). Sex is the 'original sin' that brings each new being into existence (World I 328). The term 'sexual drive' aptly describes the power of the sexual impulse, suggesting that individuals are in bondage to the slave master of the will-to-life that drives them to reproduce in order to ensure the continuance of the species. This idea is expressed several times in the novel in the thoughts of David Lurie, even though he appears not to be aware of his own bondage to the will. When he first tries to seduce his student Melanie he uses the opening lines from Shakespeare’s first sonnet which express this idea: “'From fairest creatures 
we desire increase,' he says, 'that thereby beauty's rose might never cease”” (16). Later, after he has left the city to stay with his daughter Lucy in the countryside and is walking the dogs with her - just before they are attacked and she is raped - he justifies his affair with Melanie in the terms of desire: “'My case rests on the rights of desire,' he says. 'On the god who makes even the small birds quiver'” (89). Still later, when he reflects on Lucy's rape and the motives of the rapists - unable to see the similarity in his treatment of Melanie - the following, very Schopenhauerian, image comes to his mind: “The seed of generation, driven to perfect itself, driving deep into the woman's body, driving to bring the future into being” (194). For all his reflection on the sexual impulse, Lurie appears, for much of the novel, to be unaware of his bondage to the will. However, there are moments when his will is stilled and he transcends the narrow egoistic interests that otherwise determine how he perceives the world.

One such moment occurs once he awakens after having fallen asleep in the cage of the abandoned dog Katy and engages in a discussion with his daughter, who finds him there, about the possibility of animal souls. Suddenly an inexplicable feeling overwhelms him: "A shadow of grief falls over him: for Katy, alone in her cage, for himself, for everyone” (79). He appears to experience a sense of compassion for the suffering that seems to be the lot of every living being. Significantly it is just then that he decides to help Bev Shaw in her work with abused and abandoned animals in the clinic.

He experiences a similar movement of his being - it would be inadequate to describe it as a mere intellectual reflection - when he observes the callousness of Petrus's treatment of the two sheep that he will slaughter as part of his wedding celebrations, since he tethers them up without water or grass to graze upon: “A bond seems to have come into existence between himself and the two Persians” (126). These experiences can be described as moments of grace when Lurie experiences compassion and escapes momentarily his bondage to his selfish ego.

While compassion comes naturally to several of the female characters of the novel Lucy Lurie and Bev Shaw - Lurie has to undergo suffering, what Schopenhauer called "forced resignation” (World I 392), before he attains a level of unconscious understanding of the unity of all living beings. This occurs most dramatically when he is assaulted and Lucy is raped. This crucial event is what really opens Lurie to the movement of compassion, evident in the effect the euthanizing of the dogs has on him. The moments when he breaks down in tears, which he finds inexplicable, can be seen as moments of the sundering of the veil of Maya (of the illusory 
subject/object division or the perceived separation of self and other): "The more killings he assists in, the more jittery he gets. One Sunday evening, driving home in Lucy's kombi, he actually has to stop at the roadside to recover himself. Tears flow down his face that he cannot stop; his hands shake” (142-43).

As quoted previously, for Schopenhauer, "weeping is sympathy with ourselves" [Schopenhauer's italics] (World I 377): “that we are moved to tears not by our own sufferings but by those of others happens in the following way; either in imagination we put ourselves vividly in the sufferer's place, or we see in his fate the lot of the whole of humanity, and consequently above all our own fate” (377). Thus Lurie sees his own fate, and the fate of all living beings, in the suffering and death of the dogs and the sheep, and he feels a profound sorrow for the sadness of existence. These moments of compassion are moments of salvation, although they do not last.

Schopenhauer (Ethics 184-86), using Kant's distinction between intelligible and empirical character, asserted that the intelligible character (which is part of our true, essential and noumenal nature) of each human is unique and unchangeable and is composed of varying degrees of egoism, malice and compassion (214). The empirical character, which is part of the phenomenal world and thus subject to the laws of time, space and causality can, however, change as a result of the influence of motives on our minds. We are not free, Schopenhauer argued, quoting the scholastic principle that "[d]oing follows essence” (253), except in the sense that we always act according to our intelligible nature. Mike Marais (76-77) has noted the difficulty of interpreting David Lurie's movement from an egoistic to an altruistic attitude during the course of the novel on account of several lapses into lust - in his memories of Melanie and in the moment when he meets her sister - and violence - when he assaults Pollux. This can be explained in Schopenhauerian terms: whereas Lurie's empirical character (his perception of things) does change, his predominant egoism (his intelligible character) cannot. While his libido remains powerful to the end, he comes to realize that he may not pursue his desires by any means possible. He learns both from being disciplined by the university committee and from being assaulted himself and experiencing Lucy's rape at second hand. However, his moments of transcendence are necessarily limited before his phenomenal self becomes a slave to the will once again. For Schopenhauer the moments of salvation are temporary before the powerful needs 
of the will return (World I 379), reinstating the subject/object division and bondage of the self to the will.

It seems strange, though, that Bev's compassion is expressed in her sterilization and euthanizing of animals, that her compassion seems anti-life. In fact, it seems very Schopenhauerian. The closing lines of the novel - when Lurie hands over Driepoot, the threelegged dog with whom he has formed a bond of affection, to Bev for euthanizing - are profoundly and painfully moving. Gareth Cornwell has justly expressed his dissatisfaction with interpretations that suggest that "Lurie’s is an act of benevolent self-sacrifice” (136). Michael Bell has declared that these final words of the novel - when Lurie says "'Yes, I am giving him up’” (220) - “resists, as far as I can see, analytic articulation” (189). Michiel Heyns persuasively relates this sacrifice of Driepoot to a narrative principle of perversity in which every action of Lurie, like the protagonists of Hardy's novels, leads to an undesirable consequence (58). Most interpretations, however, are based on the assumption that being is preferable to non-being, an assumption contested by Schopenhauer, Hinduism and Buddhism. It is tempting to argue that Lurie shows love to Driepoot by handing him over to be euthanized as this frees him from his bondage to the will, but that would not explain the intense emotion that most readers feel when reading the closing lines of the novel.

I suggest, instead, that we are so touched by these lines because our compassion is deeply moved in a painful sundering of the veil of Maya - the collapse of the phenomenal separation of self and other - as we sympathetically identify with Driepoot as an individual, fictional though he is, whose innocent life is prematurely, pointlessly and disgracefully cut short. We instinctively sympathize with the extinction of an irreducibly singular subjectivity. However, we also identify with him as a complex but powerful symbol of the inexplicable universal pain and suffering of existence and the awful mystery of death, a scapegoat - like Jesus and the Jews of the Holocaust - unjustly sacrificed while the living sinfully and guiltily continue to exist. The sacrifice of Driepoot brings to mind, too, the "GOD-DOG” anagram in “At the Gate," where Costello awaits judgment for her life of writing (Costello 225). As little as the closing lines make sense to us on a rational level, they move our compassion at the deepest levels of our being. They show, in fact, the power and grace of Coetzee's writing to move his readers by means of the sympathetic imagination. 
It must be pointed out that Coetzee appears to diverge from Schopenhauer most profoundly on the value of life (of individual existence) and on an ethics of asceticism. Whereas Schopenhauer writes that it is better not to have been born at all, Coetzee presents Costello as affirming life in his unpublished story "Costello in Castille," read at the opening of the Minding Animals 2 conference in Utrecht, Netherlands, on 3 July 2012. In the story, Costello's son, John, visits his mother, who has retired to a small house in an impoverished village in Spain, where she looks after dozens of (unsterilized) cats and a mentally retarded man. In the course of their discussions, Costello affirms the "sweet savour of life" and expresses her regret that she did not have more biological children during her life even if it would have meant sacrificing her literary career.

In The Death of the Animal, Coetzee reiterates the affirmation of the life principle, simultaneously pointing out a weakness in animal rights philosophy, arguing that it is not enough to speak about the right to life of animals if one does not also allow them the right to reproduce independently of human interference: "I don't see why it should be a diversion [. . . ] to reflect on the consequences of pushing for a right to life [for animals] in the absence of a right to multiply" and 'I find it hard to imagine any one of us [. . . ] saying, 'Better never to be born at all.' It is the nature of life to live" (Cavalieri 120). He also mentions the "no doubt heretical” image of clouds of souls waiting to be born (noting that it could be used as an argument against contraception) (120). Finally, in the last chapter of Inner Workings (273-76), Coetzee discusses how V.S. Naipaul critically interrogates the history and institution of Far Eastern asceticism and its dubious influence on certain Western writers, which, by implication, suggests a critical attitude, despite his fascination with Kafka's hunger-artistry, towards any ethics of asceticism, including Schopenhauer's.

In his affirmation of individual life, and in his endorsement of art as a means of salvation from suffering, thematized in the artistic activity of David Lurie and Elizabeth Costello, and in his own writing, Coetzee is undoubtedly closer to Nietzsche than Schopenhauer. Nonetheless, Schopenhauer's emphasis on suffering (including non-human suffering), his non-rationalistic ethic of compassion, and his secular interpretation of the Christian narrative of grace and salvation, help to make sense of some of the more perplexing aspects of Coetzee's work. 


\section{WORKS CITED}

Attridge, Derek. J. M. Coetzee and the Ethics of Reading: Literature in the Event. Scottsville: U of KwaZulu-Natal P, 2005.

Bell, Michael. "What Is It Like to Be a Nonracist? Costello and Coetzee on the Lives of Animals and Men.” J. M. Coetzee and the Idea of the Public Intellectual. Ed. Jayne Poyner. Athens, Ohio: Ohio UP, 2007. 172-192.

Bradshaw, Graham, and Michael Neill, eds. J.M. Coetzee’s Austerities. Farnham, Surrey: Ashgate, 2010.

Bradshaw, Graham. "Pity and Autonomy: Coetzee, Costello and Conrad. J. M. Coetzee's Austerities. Ed. Bradshaw and Neill. 191-214.

Cavalieri, Paolo. The Death of the Animal: A Dialogue. New York: Columbia UP, 2009.

Clarkson, Carrol. J. M. Coetzee: Counter Voices. London: Palgrave Macmillan, 2009.

Coetzee, J. M. Doubling the Point: Essays and Interviews. Ed. David Atwell. Cambridge, Mass: Harvard UP, 1992. . Disgrace. London: Vintage, 1999.

. The Lives of Animals. Princeton, NJ: Princeton UP, 1999.

. Stranger Shores: Essays 1986-1999. London: Vintage Books, 2001.

Elizabeth Costello. New York: Viking, 2003.

Giving Offense: Essays on Censorship. Chicago and London: U of Chicago P, 2006.

Inner Workings: Literary Essays 2000-2005. London: Harvill Secker, 2007.

"Costello in Castille." Unpublished story read at the opening of the Minding Animals 2 conference in Utrecht, Netherlands, 3 July 2012.

Cornwell, Gareth. “An Image of Animals: Speciesism in Coetzee’s Disgrace.” English Academy Review 25 (2008): 133-38.

Diamond, Cora. "The Difficulty of Reality and the Difficulty of Philosophy." Partial Answers 1/2 (2003): 1-26.

Donovan, Josephine. "Attention to Suffering: Sympathy as a Basis for Ethical Treatment of Animals.” The Feminist Care Tradition in Animal Ethics. Ed. Josephine Donovan \& Carol J. Adams. New York: Columbia UP, 2007. 174-97.

Donovan, Josephine. “'Miracles of Creation:’ Animals in J.M. Coetzee’s Work.” Michigan Quarterly Review 43.1 (2004): 78-93.

Eddins, Dwight. "Ted Hughes and Schopenhauer: The Poetry of the Will.” Twentieth Century Literature 45.1 (1999): 94-109.

Gray, John. Straw Dogs. New York: Farrar, Straus \& Giroux, 2002.

Hacking, Ian. “Our Fellow Animals.” The New York Review of Books 29 June 2000: 20-26.

Heyns, Michiel. “'Call No man Happy:’ Perversity as Narrative Principle in Disgrace.” English Studies in Africa 45.1 (2002): 57-65.

Janaway, Christopher. The Cambridge Companion to Schopenhauer. Cambridge Companions Online. http://www.4shared.com/office/vSzh_UZM/Philosophy__-The_Cambridge_Com.html. 1 June 2012. 
Kelch, Thomas G. 2007. “The Role of the Rational and the Emotive in a Theory of Animal Rights.” The Feminist Care Tradition in Animal Ethics. Ed. Josephine Donovan \& Carol J. Adams. New York: Columbia UP, 2007. 259-300.

Leist, Anton, and Peter Singer, eds. J.M. Coetzee and Ethics: Philosophical Perspectives on Literature. New York: Columbia UP, 2010.

Lowry, Elizabeth. “Like a Dog.” London Review of Books 14 October 1999: 12-14.

Marais, Mike. “J.M. Coetzee’s Disgrace and the Task of the Imagination.” Journal of Modern Literature 29.2 (2006): 75-93.

Mulhall, Stephen. The Wounded Animal: J.M. Coetzee and the Difficulty of Reality in Literature and Philosophy. Princeton \& Oxford: Princeton UP, 2009.

Northover, Richard A. “Elizabeth Costello as a Socratic Figure.” English in Africa 39.1 (2012): 37-55.

Poyner, Jayne, ed. J.M. Coetzee and the Idea of the Public Intellectual. Athens, Ohio: Ohio UP, 2007.

Schopenhauer, Arthur. Essays and Aphorisms. Trans. R. J. Hollingdale. London: Penguin Classics, 1973.

- The Two Fundamental Problems of Ethics. Trans. David E. Cartwright and Edward E. Erdmann. Oxford: Oxford UP, 2010.

• The World as Will and Representation, Vol. 1. Trans. E. F. J. Payne. New York: Dover Publications, 1969.

• The World as Will and Representation, Vol. 2. Trans. E. F. J. Payne. New York: Dover Publications, 1966.

Wright, Laurence. “Ecological Thoughts: Schopenhauer, J. M. Coetzee and Who We Are in the World.” Toxic Belonging? Ecology and Identity in South Africa. Ed. Dan Wylie. Newcastle: Cambridge Scholars Publishing, 2008. http://eprints.ru.ac.za/1041/1/Ecological_thoughts.pdf. 27 December 2012.

Wright, Laurence. “David Lurie's Learning and the Meaning of J.M. Coetzee’s Disgrace.” J.M. Coetzee's Austerities. Ed. Bradshaw and Neill. 147-62. 